\title{
Nitrogen nutriton of rice plants measured by growth and nutrient content in pot experiments. 1. Ionic balance and selective uptake
}

\author{
M. Ismunadji ${ }^{1}$ and W. Dijkshoorn
}

Institute for Biological and Chemical Research on Field Crops and Herbage, Wageningen, the Netherlands

Received: 7 July 1971

\section{Summary}

Rice plants were grown in sand culture at varying levels of supply with nitrate, ammonium and potassium. Complete analysis for the major ionic constituents showed that both plant weight and the level of carboxylates (C-A) were reduced by shortage of potassium. When, at the highest level of potassium nitrate, ammonium was substituted for nitrate with maintenance of the level of potassium supply by the addition of its equivalent of potassium sulphate, the value for (C-A) decreased from the high value with potassium nitrate $(1000 \mathrm{meq} / \mathrm{kg} \mathrm{DM})$ to a lower value of around 800 $\mathrm{meq} / \mathrm{kg} \mathrm{DM}$ and there was a further increase in plant weight and the number of tillers per plant.

From these results it was concluded that the normal value for (C-A) permitting maximum growth is exceeded if nitrate is the source of nitrogen, and that preference for ammonium is associated with a reduced rate of production of carboxylates, thus preventing accumulation of $(\mathrm{C}-\mathrm{A})$ in excess of the normal value.

It is suggested that this situation ressembles that of lime-induced chlorosis with excess carboxylates, and reference is made to literature data on chlorosis observed in rice plants fed with nitrate in place of ammonium.

\section{Introduction}

There are many instances where more successful results have been obtained by the use of ammonium in place of nitrate as the source of nitrogen for rice plants. See, for instance, Wahhab and Bhatti (1957). In the experiments of Kelly (1911), Willis and Carrers (1923), Metzger and Janssen (1928) rice grew well when nitrogen was added as ammonium, but the plants suffered from chlorosis when grown with nitrate as the sole sorce of nitrogen.

The notion then became widespread that ammonium is indispensable for the growth of rice. However, there are some records referring to improved growth of rice plants if nitrate is applied instead of ammonium. Malavolta (1954) observed that ammonium

Current address : Central Research Institute for Agriculture, Bogor, Indonesia. 
reduced the growth. He concluded that this was due to modification in photosynthesis, and based this conclusion on data from analysis for sugars and organic acids. No record was made of the organic acid content, but a lower content of organic acids is caused by the utilization of ammonium rather than by the effects of photosynthesis and respiration (Kirkby, 1969) and is not indicative of modifications in photosynthesis. Karim and Vlamis (1962) reported better growth with nitrate even when the mineral acid, produced in the medium by the utilization of the salts of ammonium, was neutralized by the addition of some solid calcium carbonate.

Although some workers refer to plant analysis results were rarely recorded. The data of Ehrler and Bernstein (1958) give the content of inorganic ions in the plant material. Summation of the metal cations $\mathrm{K}, \mathrm{Na}, \mathrm{Mg}, \mathrm{Ca}$ in milliequivalents yields the total cation content $\mathrm{C}$, and summation of the milliequivalents of the anions $\mathrm{NO}_{3}$, $\mathrm{Cl}, \mathrm{H}_{2} \mathrm{PO}_{4}, \mathrm{SO}_{4}$ the inorganic anions $\mathrm{A}$. The difference (C-A) gives the excess of metal cations over inorganic anions which accumulates in the form of the salts of the plant organic acids, further called the carboxylates (Dijkshoorn, 1969). The value for (C-A) obtained from their data is between 200 and $300 \mathrm{meq} / \mathrm{kg} \mathrm{DM}$. This low value should be related to ammonium being dominant as the nitrogenous salt supplied.

From a brief review of the data on rice it became obvious that no systematic data on the ionic constituents in rice plants grown with systematic variations in nutrient supply can be obtained from literature. Therefore, the present author decided to start with a programme designed with the aim of arriving at a diagnostic system of evaluating the nutrient status of rice plants from analytical data on the major ionic constituents akin to that developed earlier by Kostic et al. (1967) for wheat.

The experiment reported here is the first one of a series.

\section{Experimental}

Seeds were soaked in water for two days and germinated in shallow clay pots with river sand kept wet by partial submersion in water. When one week old, equally sized small seedlings were transplanted to the experimental pots. During the first two days seedlings that failed to grow were replaced by others, to make sure that each pot received four healthy seedlings. The experimental pots were prepared as follows. For each pot $7.5 \mathrm{~kg}$ of sand was thoroughly mixed with water to which were added measured quantities of normal solutions of the nutrient salts. Enough water was added to saturate the sand; $1 \mathrm{~kg}$ of unfertilized sand was then placed on top of the treated sand, and more water was added to make a water layer of $0.5 \mathrm{~cm}$ above the sand. In this way the transplanted seedlings were more gradually exposed to the high salt concentration created by the treatments. With the growth of the seedlings the depth of the water layer on top of the sand was raised to about $3 \mathrm{~cm}$ and this was maintained by frequent watering.

The rice variety used was IR-5 which is but little sensitive to day length. Temperature in the greenhouse was kept between 25 and $30^{\circ} \mathrm{C}$.

Once a week records were made of shoot length and tiller number for each pot, each treatment comprising 5 pots. The experiment was concluded 48 days after sowing. The tops were harvested by cutting at a height of $7 \mathrm{~cm}$ above the sand surface, the remaining plant parts consisting of roots plus stubbles were thoroughly freed from sand with running tap water. The material was dried, powdered, and stored for analysis. The treatments are listed in Table 1. 
Table 1. List of treatments. In Series $\mathrm{a}_{1} \mathrm{Na}$ was replaced by $\mathrm{K}$; in an $\mathrm{Ca}$ was replaced by $\mathrm{K}$. In b $\mathrm{NO}_{3}$ substitutes for $\mathrm{Cl}\left(\mathrm{b}_{1}\right)$ or $\mathrm{SO}_{4}\left(\mathrm{~b}_{2}\right)$. Treatments $\mathrm{c}$ were applied at constant $\mathrm{N}$ with stepwise substitution of $\mathrm{NH}_{4}$ and $\mathrm{K}$ for $\mathrm{KNO}_{3}$, using the chlorides $\left(\mathrm{c}_{1}\right)$, the monophosphates $\left(\mathrm{c}_{2}\right)$, or the sulphates $\left(c_{3}\right)$ of ammonium and potassium. Replacement was made in five discrete steps with $\mathrm{x}=0$, $10,20,30$ or 40 . Subdivisions of abscissae in Fig. 2, 4, 6 and 7 denote the chosen values for $x$. Column on the right indicates elements that varied in the supply with the nutrient salts.

Iron and other trace elements supplied are not recorded. The medium was sand with no organic matter and very little nutrients in it. The added salt solutions were diluted by adding $1.5 \mathrm{l}$ of water to the treated sand which was kept flooded by frequent watering throughout the period of growth.

\begin{tabular}{|c|c|c|c|c|c|c|c|c|c|c|}
\hline \multirow[t]{2}{*}{ Code } & \multirow[t]{2}{*}{ Treatment } & \multicolumn{8}{|c|}{ Milliequivalents per pot } & \multirow{2}{*}{$\begin{array}{l}\text { Variation } \\
\text { in: }\end{array}$} \\
\hline & & $\bar{N}$ & $\mathrm{Cl}$ & $\mathbf{P}$ & $S$ & $\mathbf{K}$ & $\mathrm{Na}$ & $\mathbf{M g}$ & $\mathrm{Ca}$ & \\
\hline$a_{1}$ & $\begin{array}{l}\mathrm{x} \mathrm{KNO}_{3} \\
(40-x) \mathrm{NaNO}_{3}\end{array}$ & 40 & 0 & 20 & 20 & $\begin{array}{r}0 \\
1 \\
40\end{array}$ & $\begin{array}{r}40 \\
1 \\
0\end{array}$ & 20 & 20 & $\mathrm{~K}, \mathrm{Na}$ \\
\hline $\mathrm{a}_{2}$ & $\begin{array}{l}\mathrm{X} \mathrm{KNO}_{3} \\
(40-\mathrm{x}) \mathrm{Ca}\left(\mathrm{NO}_{3}\right)_{2}\end{array}$ & 40 & 0 & 20 & 20 & $\begin{array}{r}0 \\
40\end{array}$ & 0 & 20 & 20 & $\mathrm{~K}, \mathrm{Ca}$ \\
\hline$b_{1}$ & $\begin{array}{l}\mathrm{x} \mathrm{KNO}_{3} \\
(40-\mathrm{x}) \mathrm{KCI}\end{array}$ & $\begin{array}{r}0 \\
1 \\
40\end{array}$ & $\begin{array}{r}40 \\
0\end{array}$ & 20 & 20 & 40 & 0 & 20 & 20 & $\mathrm{~N}, \mathrm{Cl}$ \\
\hline$b_{2}$ & $\begin{array}{l}\mathrm{x} \mathrm{KNO}_{3} \\
(40-\mathrm{x}) \mathrm{K}_{2} \mathrm{SO}_{4}\end{array}$ & $\begin{array}{r}0 \\
40\end{array}$ & 0 & 20 & $\begin{array}{l}60 \\
1 \\
20\end{array}$ & 40 & 0 & 20 & 20 & $\mathrm{~N}, \mathrm{~S}$ \\
\hline $\mathrm{c}_{1}$ & $\begin{array}{l}x \mathrm{NH}_{4} \mathrm{Cl} \\
\times \mathrm{KCl} \\
(40-\mathrm{x}) \mathrm{KNO}_{3}\end{array}$ & 40 & $\begin{array}{r}0 \\
1 \\
80\end{array}$ & 20 & 20 & 40 & 0 & 20 & 20 & $\begin{array}{l}\text { form of } \mathbf{N} \text {, } \\
\mathrm{Cl}\end{array}$ \\
\hline $\mathbf{c}_{2}$ & $\begin{array}{l}x\left(\mathrm{NH}_{4}\right) \mathrm{H}_{2} \mathrm{PO}_{4} \\
x \mathrm{KH}_{2} \mathrm{PO}_{4} \\
(40-x) \mathrm{KNO}_{3}\end{array}$ & 40 & 0 & $\stackrel{20}{100}$ & 20 & 40 & 0 & 20 & 20 & $\begin{array}{l}\text { form of } N, \\
P\end{array}$ \\
\hline $\mathrm{c}_{3}$ & $\begin{array}{l}x\left(\mathrm{NH}_{4}\right)_{2} \mathrm{SO}_{4} \\
\times \mathrm{K}_{2} \mathrm{SO}_{4} \\
(40-\mathrm{x}) \mathrm{KNO}_{3}\end{array}$ & 40 & 0 & 20 & $\underbrace{20}_{100}$ & 40 & 0 & 20 & 20 & $\begin{array}{l}\text { form of } N \text {, } \\
S\end{array}$ \\
\hline
\end{tabular}

\section{Results}

The geometry of the main response of dry weight to the treatments is illustrated by the graphs of Fig. 1, drawn in a logarithmic form. If $\mathrm{K}$ was applied to plants short of potassium the dry weight of the tops increased in proportion to that of the whole

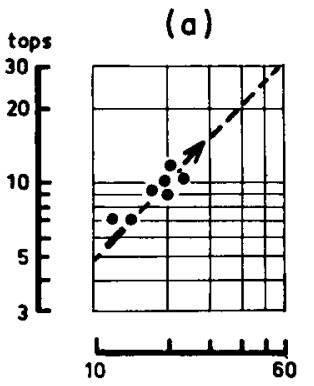

(b)

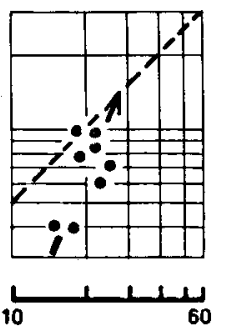

(c)

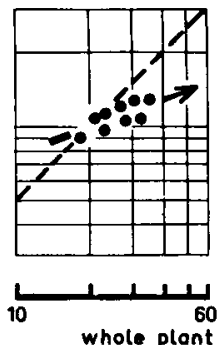

Fig. 1. Change in grams dry matter per pot for tops and whole plants when potassium (a) or nitrate (b) was supplied to a depleted culture, and when at the highest $\mathbf{N}$ level nitrate was replaced by ammonium (c). 
plant (a). If nitrate was supplied to the depleted culture the tops contributed relatively more to the increase in dry weight (b). If, at the highest level of nitrate, this ion was replaced by ammonium, there was a marked further increase in dry weight of the whole plant but the tops made a relatively smaller contribution to the gain in dry weight (c). The increment due to substitution of ammonia for nitrate will appear to be associated with an increase in the number of tillers.

These data refer to the dry weights at harvest when the experiment was concluded. The course of growth with time can be shown indirectly by data on tiller number and plant height which were recorded at regular intervals of one week. The product of these two figures is further called the total shoot length and expressed as meters per plant. Each value is the mean of the 16 plants per treatment.

The records give a family of curves for shoot length per plant against treatment. Any one curve is fixed in its position by the time of observation in days after transplanting to the treated pots, viz 7, 14, 21, 28 and 35 days.

For Treatments b where nitrate was stepwise substituted for chloride or sulphate in the nutrient salts, the results are shown in Fig. 2. Very little growth was obtained when no nitrogen was added with the nutrient salts and after two weeks the plants ceased to grow.

At the higher levels of nitrate application the curves approach the broken straight line drawn with the assumption of exponential growth with a slope corresponding to a two-fold increase in shoot length per six days. Between the fourth and the fifth week the growth proceeded much slower.

The nitrogen requirements can be roughly judged from total shoot length in the following way. It was found that shoot length varied about proportional to the dry weight of the tops with $0.4 \mathrm{~g}$ DM per meter of shoot length. Further, it appeared that with adequate supply of nitrogen the dried material contained $2.5 \mathrm{meq} \mathrm{N} / \mathrm{g}$, the $\mathrm{N}$ being expressed as the ion equivalent of nitrate or ammonium. Hence, the produc-

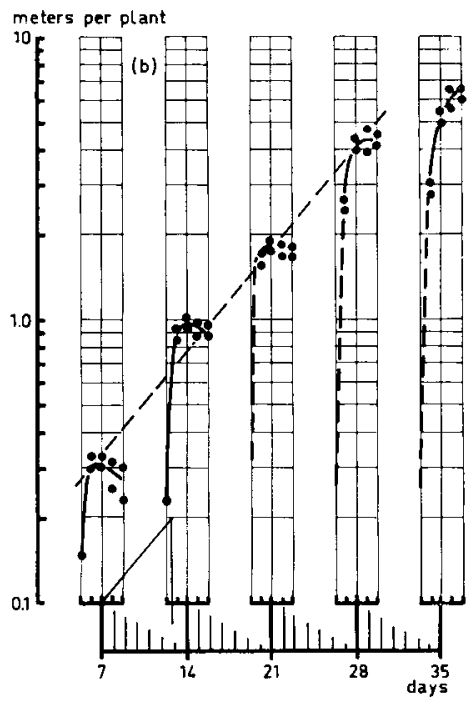

Fig. 2. Sum of lengths of shoots in meters per plant during the successive weeks after transfer of the seedlings to the treated pots. Each curve fits the points for 5 levels of nitrate in the fertilizer: $0,10,20,30,40$ meq per pot (treatments b of Table 1). The slope of the broken line indicates that total shoot length increased two-fold in about 6 days. 
tion of $1 \mathrm{~m}$ shoot length requires the incorporation of $1 \mathrm{meq}$ nitrogen in the tops. Since the proportion of $\mathrm{N}$ in the tops appeared to be about two-third of the $\mathrm{N}$ in the whole plant (see Fig. 5) we may substitute for this about $1.5 \mathrm{meq}$ in the whole plant. Since each pot contained 4 plants, $1 \mathrm{~m}$ shoot length per plant requires 6 meq $\mathrm{N}$ per pot to maintain the adequate level of $\mathrm{N}$ in the tissues. Any further increase in plant size in excess of this proportion is depleted growth, and the growth and $\mathrm{N}$ concentration of the plants will be increased by the addition of more nitrogen.

As a means of defining the nitrogen status of the plants during the progress of the experiment this is a great convenience. As will be shown below many differences in plant composition observed in the present experiment can be attributed solely to variation in dry weight production at more or less advanced exhaustion of nitrogen.

Fig. 2 shows that during the first three weeks there was no increase in plant size when the nitrate supply was increased from 10 to 40 meq per pot. Shoot length increased to $1.8 \mathrm{~m}$ per plant and, at that time, the $\mathrm{N}$ required was $11 \mathrm{meq}$ per pot which is near to $10 \mathrm{meq}$. At this stage the higher additions were in excess of the actual growth requirements and had no effect. At the fourth week the plants of the 10 -meq treatment had made $2.5 \mathrm{~m}$ shoot length and the requirements were $15 \mathrm{meq} \mathrm{N}$. These plants were deficient at this stage, and the nitrogen concentration within the tissues must have dropped to about two-third of the adequate concentration. Here, the further increase in nitrate supply had a considerable effect on plant size. At the level of $6 \mathrm{~m}$ shoot length per plant, reached after five weeks, the nitrogen requirement must have been $36 \mathrm{meq}$ per pot, so that at the highest level of application (40 meq per pot) the available $\mathbf{N}$ was near to exhaustion. This is roughly confirmed by the evidence from plant analysis to be discussed below.

With no nitrate in the nutrient salts the plants made $0.3 \mathrm{~m}$ shoot length so that only a few milliequivalents of $\mathbf{N}$ came from the unfertilized sand plus the small seedlings brought into the experiment.

From the data on dry weight and nitrogen concentration in the tops and in the roots and stubbles, the total $\mathrm{N}$ absorbed by the plants at harvest was calculated. For Treatments $b$ the values are plotted in Fig. 3 against the nitrate added to the pots.

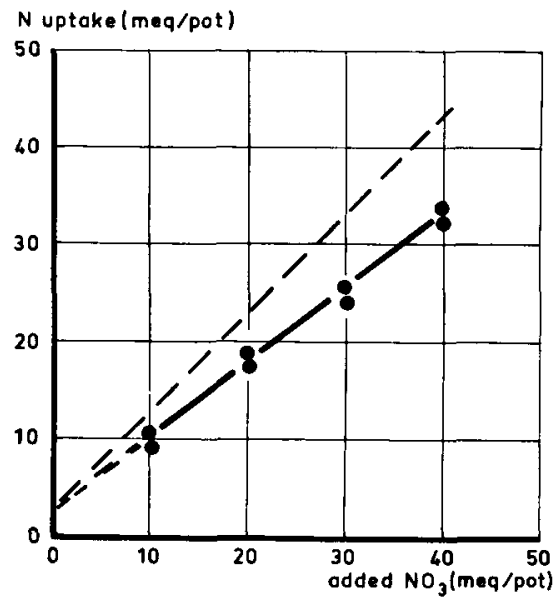

Fig. 3. Nitrogen in the whole plants in milliequivalents per pot against the milliequivalents per pot added with the fertilizer for Treatments $b$ with nitrate as the sole source of N. Disproportionality was due to some $3 \mathrm{meq}$ coming from seedlings and unfertilized sand. The proportion not recovered is attributed to co-consumption by algae in the water layer above the sand. 
A straight line was obtained which intercepts the ordinate at 3 meq per pot where the $\mathrm{N}$ came from the unfertilized pots. The broken line would represent the result if all the added nitrate were absorbed by the plants. The full line through the points indicates a deficit of about one-fourth of the nitrate added. Since even at the highest level of application the plants were somewhat deficient in $N$, this deficit was not available to the plants.

As will appear presently this deficit in the $\mathrm{N}$ balance of the experiment is not brought about by denitrification. There is no other evidence than that it came from consumption of $\mathrm{N}$ by the algae growing in the water layer on top of the sand. The pots with no nitrogen were practically free from algae but with the increase in nitrate more algae developed which will have consumed available $\mathrm{N}$ in a certain proportion with the $\mathrm{N}$ absorbed by the growing plants. Since algae contain about $5 \mathrm{meq} \mathrm{N} / \mathrm{g} \mathrm{DM}$, only $2 \mathrm{~g}$ dry weight of algae would suffice to absorb the $10 \mathrm{meq}$ of $\mathrm{N}$ not recovered by the plants at the 40-meq level.

For the three sets of Treatments $c$ where nitrate was stepwise replaced by ammonium in the nutrient salts the value for shoot length per plant are summarized in Fig. 4. Again, the increase in average plant size with time of growth crudely suggests exponential growth, shoot length being doubled within six days. After the fourth week the relative rate of growth was reduced. In the series $c_{1}$ and $c_{2}$, where ammonium chloride and ammonium phosphate was used, and the supply with potassium was maintained by adding the equivalent amount of potassium chloride and phosphate, respectively, each of the curves for one date passes through an optimum centered at the treatment $20 \mathrm{meq}$ nitrate plus $20 \mathrm{meq}$ ammonium. But in the series with the sulphates of ammonium and potassium $\left(\mathrm{c}_{3}\right)$ the biggest plants were obtained with 40 meq ammonium alone.

From plant composition there came no evidence that this difference should be related to plant nutrition per se. The difference in growth response seems determined primarily by the much greater increase in osmotic pressure of the medium when the monovalent chlorides or phosphates were used in place of the divalent sulphates to substitute ammonium for potassium nitrate and to keep the potassium milli-equivalent supply constant.

In the medium the ion milliequivalents listed in Table 1 were dissolved in 1.51 water. By way of illustration these values were converted into moles and, considering the valence of all ion species, the osmotically active concentration was calculated for chloride, phosphate, and sulphate in the corresponding series of treatments. For the treatments with ammonium alone the osmotically active concentrations were: for the monovalents chloride and phosphate 0.038; and for the divalent sulphate 0.006 .

The rice plants were found to be rather sensitive to the relatively high concentrations resulting from the addition of the nutrient salts required for the expected growth in one gift, and it may well be so here that the promoting effect of substitution of ammonium for nitrate was superimposed by an inhibiting effect of the stepwise increase in osmotic pressure in Series $c_{1}$ and $c_{2}$. From this it would follow that the true preference for ammonium alone was best reflected by the continuous increase in plant size when ammonium and potassium were introduced as the sulphates (Series $c_{3}$ ), thus reducing the increment in osmotic stress which interfered with the growth of the ammonium plants that received chlorides or phosphates of ammonium and potassium $\left(c_{1}\right.$ and $c_{2}$ ).

Parallel plots of the tiller number for the various dates in Fig. 4 reveals another interesting detail. If the length of the plants were a constant, the points for tiller 

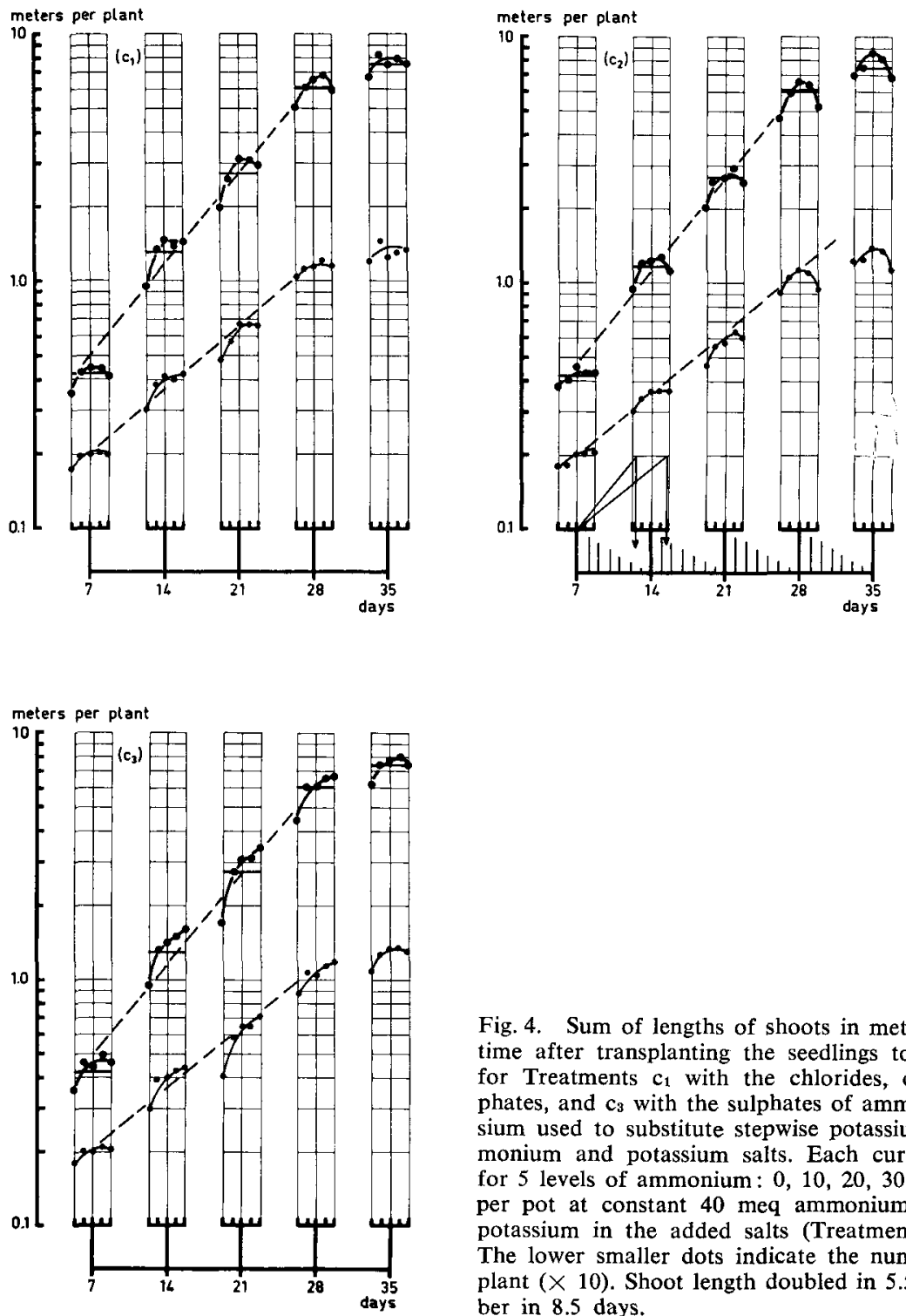

Fig. 4. Sum of lengths of shoots in meters per plant with time after transplanting the seedlings to the treated pots for Treatments $c_{1}$ with the chlorides, $c_{2}$ with the phosphates, and $c_{3}$ with the sulphates of ammonium and potassium used to substitute stepwise potassium nitrate by ammonium and potassium salts. Each curve fits the points for 5 levels of ammonium: $0,10,20,30$ and 40 meq $\mathrm{NH}_{4}$ per pot at constant $40 \mathrm{meq}$ ammonium plus nitrate and potassium in the added salts (Treatments $c$ of Table 1). The lower smaller dots indicate the number of tillers per plant $(\times 10)$. Shoot length doubled in 5.5 days, tiller number in 8.5 days.

number would be arranged along curves on the log scale congruent to those for shoot lenght. The curves conform to this because the main effect of substitution of ammonium for nitrate is an increase in the number of tillers.

With time of growth the length of the plants increased so that the lines for shoot length and tiller number diverge from one week to the other. These straight broken lines through the average shoot length and tiller number suggest that both quantities 
increased with time in an exponential fashion. Tiller number was doubled in 9 days and plant total shoot length in about 6 days. For ryegrass and maize these times were for dry weight 10 and 7 days, respectively. This shows that rice is a fast growing species.

It was shown (Fig. 3) that the amount of nitrogen absorbed by the plants was only about $75 \%$ of the nitrate supplied with the nutrient salts.

Fig. 5 shows the amount of milliequivalents of organic nitrogen in the whole plants per pot. The values were obtained from the dry weight and nitrogen concentration in the tops and in the roots plus stubbles collected from the pots of treatments (c) at harvest. Since the nitrate concentration in the tissues was negligible compared with organic nitrogen, and the small seedlings used for transplanting to the treated pots had little nitrogen within them, the values practically represent the amount of nitrogen absorbed from the treated pots.

The data of Fig. 5 were all from the 40 meq nitrogen level where nitrate was stepwise replaced by ammonium. The weight of the plants varied greatly with the proportion of ammonium and nitrate in a way similar to that for shoot length. But the amount of nitrogen absorbed by the plants was constant at 32 meq per pot, independent of the weight of the plant. This shows that at the highest level of nitrogen applied (40 meq per pot) the plants had absorbed all the available nitrogen, otherwise the heavier plants would have absorbed more nitrogen than the lighter ones. This is confirmed by the low nitrate concentration in the tissues of the plants grown with nitrate.

Since the $\mathrm{N}$ absorbed was equal to the available $\mathrm{N}$, available $\mathrm{N}$ was the same throughout the experiment, irrespective of form of nitrogen supplied. Hence, denitrification in the flooded sand free of organic matter was beyond the measurable.

The exhaustion of available nitrogen at the 40 meq level of application can be roughly judged to have commenced after the fourth week. Since the plants were harvested after the sixth week of growth, there was a final period of two weeks wherein all the plants utilized their nutrient salts in a similar way, absorbing metal cations
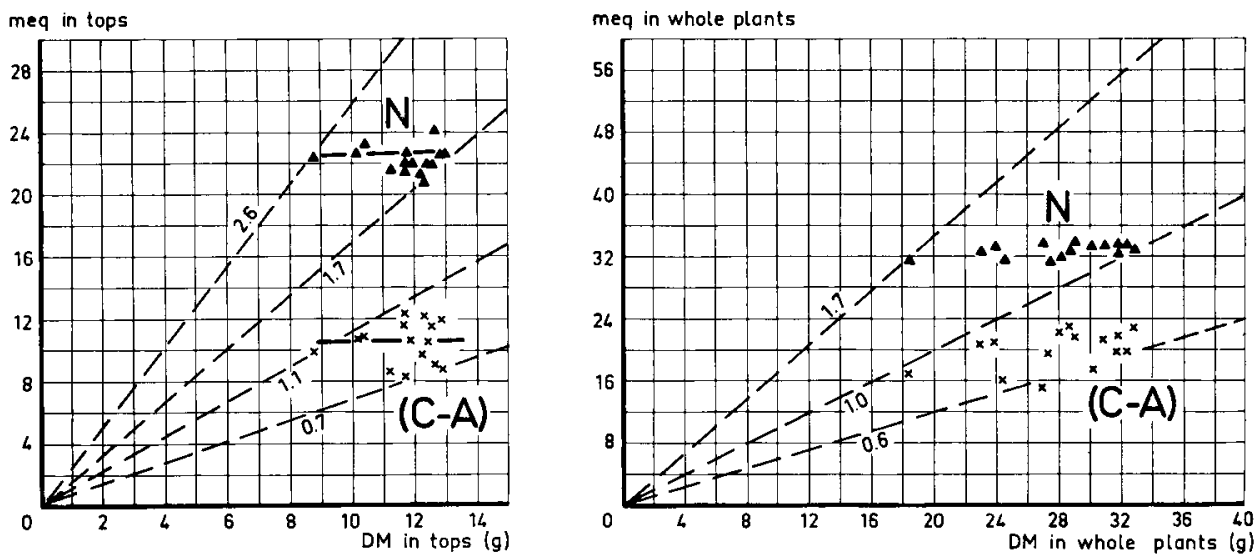

Fig. 5. Assimilated nitrogen (meq) in the tops and in the whole plants against DM per pot. Data for Treatments c. With substitution of ammonium for nitrate the dry weight increased without change in assimilated nitrogen, indicating that all available $\mathrm{N}$ was absorbed and that no nitrate was lost by denitrification in the flooded sand. Carboxylates $(\mathrm{C}-\mathrm{A})$ accumulate at about one-half the equivalent of organic nitrogen. 
in balance with inorganic anions including bicarbonate (Dijkshoorn et al., 1968), and no nitrogen. Consequently, the effect of form of nitrogen was reduced by subsequent depleted growth. Further, any change in treatment resulting in an increase in dry weight will reduce the concentration of nitrogen because the available amount is

Table 2. Yield (g DM per pot), main ionic constituents (meq/kg DM), and organic (assimilated) nitrogen in ion meq of nitrate or ammonium consumed to produce the organic $\mathbf{N}$ per $\mathrm{kg}$ DM. Values for $\mathrm{NO}_{3}$ and $\mathrm{SO}_{4}$ refer to the unchanged ionic form in the plant material, not consumed by metabolism. Nitrate values lower than 10 should be qualified as no nitrate in the tissues.

For specification of treatments, see Table 1 with $\mathrm{x}=0,10,20,30$ and 40 , respectively.

All data for tops only.

By summation of the metal cations (C) and of the inorganic anions (A) a value (C-A) is obtained for the excess of metal cations over inorganic anions which gives the numerical value for the metal cations present as carboxylates, the salts of the organic plant acids (malate, citrate, oxalate, etc. plus a small proportion of structural carboxylic compounds, the polyronates) in meq $/ \mathrm{kg} \mathrm{DM}$.

\begin{tabular}{|c|c|c|c|c|c|c|c|c|c|c|}
\hline $\begin{array}{l}\text { Treat- } \\
\text { ment }\end{array}$ & Yield & $\mathrm{K}$ & $\mathrm{Na}$ & $\mathrm{Mg}$ & $\mathrm{Ca}$ & $\mathrm{NO}_{3}$ & $\mathrm{Cl}$ & $\mathrm{H}_{2} \mathrm{PO}_{4}$ & $\mathrm{SO}_{4}$ & Org. $\mathbf{N}$ \\
\hline$a_{1}$ & $\begin{array}{r}7.1 \\
9.1 \\
9.4 \\
9.7 \\
10.1\end{array}$ & $\begin{array}{l}174 \\
591 \\
727 \\
827 \\
870\end{array}$ & $\begin{array}{r}498 \\
90 \\
26 \\
11 \\
5\end{array}$ & $\begin{array}{l}423 \\
326 \\
258 \\
267 \\
252\end{array}$ & $\begin{array}{l}311 \\
335 \\
298 \\
312 \\
307\end{array}$ & $\begin{array}{r}81 \\
23 \\
10 \\
14 \\
6\end{array}$ & $\begin{array}{l}130 \\
116 \\
104 \\
104 \\
104\end{array}$ & $\begin{array}{r}126 \\
106 \\
100 \\
100 \\
94\end{array}$ & $\begin{array}{l}135 \\
109 \\
103 \\
133 \\
110\end{array}$ & $\begin{array}{l}2811 \\
2595 \\
2368 \\
2386 \\
2234\end{array}$ \\
\hline$a_{2}$ & $\begin{array}{r}7.2 \\
10.4 \\
9.3 \\
9.4 \\
9.6\end{array}$ & $\begin{array}{l}159 \\
571 \\
747 \\
829 \\
878\end{array}$ & $\begin{array}{r}133 \\
15 \\
8 \\
7 \\
6\end{array}$ & $\begin{array}{l}384 \\
278 \\
275 \\
252 \\
264\end{array}$ & $\begin{array}{l}445 \\
381 \\
356 \\
323 \\
303\end{array}$ & $\begin{array}{r}27 \\
6 \\
16 \\
10 \\
16\end{array}$ & $\begin{array}{r}150 \\
116 \\
107 \\
110 \\
99\end{array}$ & $\begin{array}{r}106 \\
90 \\
100 \\
100 \\
100\end{array}$ & $\begin{array}{r}119 \\
75 \\
123 \\
117 \\
123\end{array}$ & $\begin{array}{l}2773 \\
2200 \\
2578 \\
2459 \\
2464\end{array}$ \\
\hline$b_{1}$ & $\begin{array}{l}- \\
3.8 \\
6.8 \\
8.3 \\
9.1\end{array}$ & $\begin{array}{r}- \\
780 \\
747 \\
885 \\
926\end{array}$ & $\begin{array}{r}- \\
4 \\
4 \\
4 \\
5\end{array}$ & $\begin{array}{l}- \\
254 \\
224 \\
256 \\
265\end{array}$ & $\begin{array}{l}- \\
379 \\
338 \\
302 \\
302\end{array}$ & $\begin{array}{l}-11 \\
11 \\
11 \\
36\end{array}$ & $\begin{array}{l}- \\
437 \\
412 \\
395 \\
113\end{array}$ & $\begin{array}{r}- \\
103 \\
94 \\
90 \\
103\end{array}$ & $\begin{array}{r}- \\
189 \\
118 \\
113 \\
121\end{array}$ & $\begin{array}{r}-\overrightarrow{1360} \\
1520 \\
2058 \\
2616\end{array}$ \\
\hline$b_{2}$ & $\begin{array}{l}- \\
4.0 \\
6.4 \\
7.7 \\
9.5\end{array}$ & $\begin{array}{l}- \\
862 \\
844 \\
893 \\
850\end{array}$ & $\begin{array}{r}- \\
4 \\
4 \\
11 \\
6\end{array}$ & $\begin{array}{l}-192 \\
221 \\
257 \\
255\end{array}$ & $\begin{array}{l}- \\
341 \\
339 \\
323 \\
318\end{array}$ & $\begin{array}{r}- \\
6 \\
6 \\
8 \\
11\end{array}$ & $\begin{array}{r}- \\
206 \\
152 \\
118 \\
113\end{array}$ & $\begin{array}{r}- \\
100 \\
97 \\
103 \\
94\end{array}$ & $\begin{array}{l}- \\
230 \\
185 \\
165 \\
144\end{array}$ & $\begin{array}{r}- \\
1285 \\
1548 \\
2267 \\
2412\end{array}$ \\
\hline$c_{1}$ & $\begin{array}{l}10.3 \\
12.2 \\
12.6 \\
12.7 \\
11.7\end{array}$ & $\begin{array}{l}839 \\
798 \\
803 \\
803 \\
798\end{array}$ & $\begin{array}{l}4 \\
4 \\
5 \\
5 \\
5\end{array}$ & $\begin{array}{l}238 \\
219 \\
249 \\
258 \\
260\end{array}$ & $\begin{array}{l}313 \\
320 \\
329 \\
336 \\
355\end{array}$ & $\begin{array}{r}6 \\
10 \\
11 \\
10 \\
10\end{array}$ & $\begin{array}{l}104 \\
381 \\
471 \\
513 \\
542\end{array}$ & $\begin{array}{r}94 \\
87 \\
87 \\
90 \\
100\end{array}$ & $\begin{array}{r}140 \\
98 \\
103 \\
98 \\
75\end{array}$ & $\begin{array}{l}2257 \\
1762 \\
1680 \\
1773 \\
1956\end{array}$ \\
\hline $\mathrm{c}_{2}$ & $\begin{array}{l}10.2 \\
11.7 \\
11.9 \\
12.8 \\
11.2\end{array}$ & $\begin{array}{l}857 \\
824 \\
855 \\
819 \\
768\end{array}$ & $\begin{array}{l}6 \\
5 \\
5 \\
5 \\
8\end{array}$ & $\begin{array}{l}239 \\
230 \\
212 \\
195 \\
207\end{array}$ & $\begin{array}{l}303 \\
301 \\
250 \\
256 \\
264\end{array}$ & $\begin{array}{l}5 \\
5 \\
5 \\
5 \\
5\end{array}$ & $\begin{array}{r}116 \\
107 \\
99 \\
99 \\
96\end{array}$ & $\begin{array}{r}90 \\
110 \\
158 \\
187 \\
203\end{array}$ & $\begin{array}{r}129 \\
131 \\
69 \\
164 \\
189\end{array}$ & $\begin{array}{l}2235 \\
1847 \\
1847 \\
1710 \\
1927\end{array}$ \\
\hline$c_{3}$ & $\begin{array}{r}8.9 \\
11.7 \\
12.2 \\
12.8 \\
12.6\end{array}$ & $\begin{array}{l}878 \\
809 \\
780 \\
788 \\
788\end{array}$ & $\begin{array}{l}4 \\
5 \\
4 \\
6 \\
7\end{array}$ & $\begin{array}{l}275 \\
232 \\
223 \\
215 \\
208\end{array}$ & $\begin{array}{l}315 \\
328 \\
315 \\
320 \\
332\end{array}$ & $\begin{array}{r}26 \\
6 \\
6 \\
5 \\
6\end{array}$ & $\begin{array}{l}113 \\
102 \\
107 \\
107 \\
104\end{array}$ & $\begin{array}{l}97 \\
87 \\
84 \\
94 \\
84\end{array}$ & $\begin{array}{l}125 \\
136 \\
146 \\
205 \\
224\end{array}$ & $\begin{array}{l}2535 \\
1880 \\
1697 \\
1744 \\
1754\end{array}$ \\
\hline
\end{tabular}




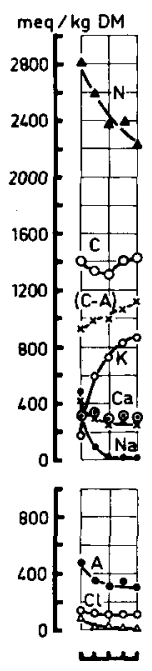

$a_{1}$
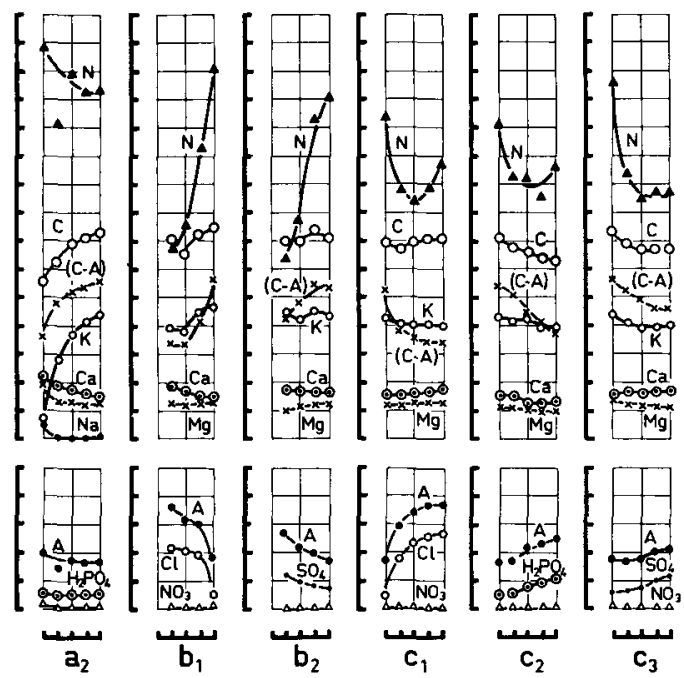

Fig. 6. Main ionic constituents in the tops in milliequivalents per $\mathrm{kg}$ dried material. Subdivision of abscisses is: $0,10,20,30$ and $40 \mathrm{meq}$ pot of potassium ( $a_{1}$ and $\left.a_{2}\right)$, of nitrate $\left(b_{1}\right.$ and $\left.b_{2}\right)$, and of ammonium for nitrate at the $40 \mathrm{meq}$ of $\mathrm{N}$ per pot level $\left(c_{1}, c_{2}\right.$ and $\left.c_{3}\right)$. For further details of ion replacement in the nutrient salts, compare Table 1 . The fall in $\mathbf{N}$ level for Treatments a and $c$ is due to dilution by increased growth following the introduction of potassium or ammonium.

further diluted by the growth. This should be kept in mind while discussing the effects on plant composition.

The greater part of the nutrients absorbed from the soil accumulate in the tops which were analyzed in detail (Table 2). The remaining parts, roots plus stubbles, were analyzed only for $\mathrm{N}$, nitrate, and ash-alkalinity as the basis for determining $\mathrm{N}$ and (C-A) (van Tuil et al., 1964) for the whole plants as well (Fig. 5). Since the tops have been given prominence in the literature on plant nutrition, and whole plant composition, although on a lower level, behaves quite similar, only the composition of the tops are summarized in Fig. 6.

In Series a with varying potassium supply the plants receiving no $\mathrm{K}$ had levels below $200 \mathrm{meq} / \mathrm{kg}$ indicating severe deficiency (van Tuil, 1965). With the increase in $\mathrm{K}$ there was a marked decline in the concentration of $\mathrm{N}$ because the amount absorbed was further diluted by the improved growth, no further $\mathrm{N}$ being available to maintain its initial concentration when the plants made more dry matter.

Where $\mathrm{K}$ substitutes for $\mathrm{Na}\left(\mathrm{a}_{1}\right)$ the opposed curvature of the lines for these two ions indicate competitive uptake and this is confirmed by the increase in $\mathrm{Na}$ when $\mathrm{K}$ was replaced by $\mathrm{Ca}$ at constant supply with $\mathrm{Na}\left(\mathrm{a}_{2}\right)$. The uptake of $\mathrm{Mg}$ was promoted by the absence of $\mathrm{K}$ in a similar way. The straight lines for $\mathrm{Ca}$ indicates absence of competition between $\mathrm{Ca}$ and the monovalent cations. The dominance of $\mathrm{K}$ and the competitive effects are similar to the situation described for some grass species by de Wit et al. (1963).

In Series a the dry weight varied with the level of $K$. Therefore, concentration ratios cannot be substituted for uptake ratios. The values for uptake by the tops, 


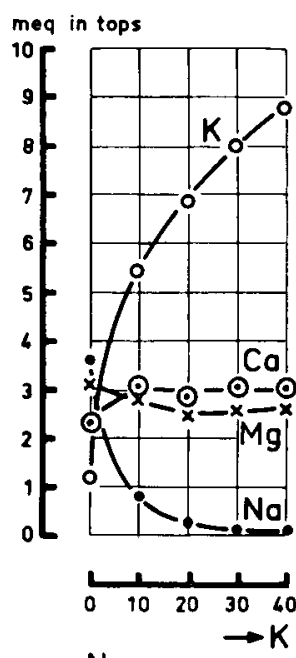

No

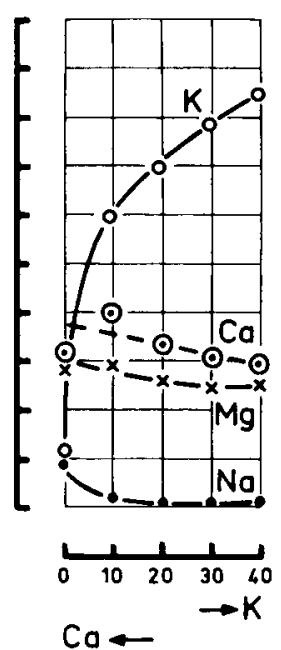

$\mathrm{Ca} \leftarrow$
Fig. 7. Uptake of cations by the tops transferred into absolute amounts (meq) absorbed per pot. Data from Treatments a.

obtained by multiplying dry weight and concentration, are summarized in Fig. 7 . Here, translation of the data of concentrations into uptakes does not interfere with the qualitative conclusions.

The decline of concentration of carboxylates, (C-A), with shortage of $\mathrm{K}$ is common among gramineous plants where the accumulation of metal cations $(C)$ is mainly delegated to $\mathrm{K}$. Since plants deficient of $\mathrm{K}$ absorb $\mathrm{Na}$ more readily than $\mathrm{Ca}$, substitution of $\mathrm{Na}$ for $\mathrm{K}$ brought about a smaller decrease in (C-A), and a more elevated water content in their tissues compared with the plants that received $\mathrm{Ca}$ for $\mathrm{K}$. It was only in the case of $\mathrm{Ca}$ for $\mathrm{K}$ that the plants showed an increase in dry matter percentage in the magnitude of plants receiving but little nitrogen (Table 3 ).

The effect of increasing the nitrate supply is shown by Series $b$. Where no nitrate was added the material was insufficient for analysis. From the 10-meq level upwards organic nitrogen rose from 1400 to $2600 \mathrm{meq} / \mathrm{kg}$ dry matter.

In Series $b$ with varying nitrogen supply the carboxylate concentration drops to lower levels when chloride is substituted for nitrate (b) than when sulphate is used as the replacing anion $\left(b_{2}\right)$. The greater accumulation of chloride and its depressive effect on the level of carboxylates merely confirm this effect of chloride-containing nutrient salts (van Tuil, 1965). In the series where nitrate was replaced by ammonium the carboxylate level falls when ammonium is substituted for nitrate. In Series $c_{1}$ and $c_{2}$ the curves for nitrogen show a minimum located at $50 \%$ substitution where the plants performed the greatest growth. In Series $c_{3}$ the nitrogen level falls continuously and the best growth was obtained at $100 \%$ substitution (compare Fig. 4). Since the available $\mathrm{N}$ was constant (Fig. 5) and all of it was absorbed, the observed trend of $\mathrm{N}$ concentration with treatment reflects solely dilution by growth under conditions of some shortage of nitrogen. Although the fall in the level of carboxylates (C-A) is doubtless connected with the introduction of ammonium (compare for instance Kirkby, 1969), some caution is necessary in efforts to relate the partially depleted growth with the (C-A) level, as done by de Wit et al. (1963). Nevertheless, it seems at first sight 
Table 3. Percentage of dry matter in the fresh material of the plants grown at varying potassium (Series a) and nitrate (Series b) supply. Mean of 5 replicates with standard error of the mean.

\begin{tabular}{|c|c|c|c|c|c|}
\hline \multicolumn{3}{|c|}{ Treatment $a_{1}$} & \multicolumn{3}{|c|}{ Treatment $a_{2}$} \\
\hline \multicolumn{2}{|c|}{$\mathrm{meq} / \mathrm{pot}$} & \multirow[t]{2}{*}{ DM $(\%)$} & \multicolumn{2}{|c|}{$\mathrm{meq} / \mathrm{pot}$} & \multirow[t]{2}{*}{$\mathrm{DM}(\%)$} \\
\hline $\mathrm{K}$ & $\mathrm{Na}$ & & $\mathbf{K}$ & $\mathrm{Ca}$ & \\
\hline 0 & 40 & $21.4 \pm 0.4$ & 0 & 60 & $24.2 \pm 0.3$ \\
\hline 10 & 30 & $20.5 \pm 0.2$ & 10 & 50 & $23.1 \pm 0.2$ \\
\hline 20 & 20 & $20.7 \pm 0.8$ & 20 & 40 & $20.9 \pm 0.3$ \\
\hline 30 & 10 & $20.8 \pm 0.5$ & 30 & 30 & $21.2 \pm 0.3$ \\
\hline 40 & 0 & $20.8 \pm 0.3$ & 40 & 20 & $20.1 \pm 0.2$ \\
\hline \multicolumn{3}{|c|}{ Treatment $b_{1}$} & \multicolumn{3}{|c|}{ Treatment $b_{2}$} \\
\hline \multicolumn{2}{|c|}{ meq/pot } & \multirow[t]{2}{*}{ DM (\%) } & \multicolumn{2}{|c|}{$\mathrm{meq} / \mathrm{pot}$} & \multirow[t]{2}{*}{ DM (\%) } \\
\hline $\mathrm{NO}_{3}$ & $\mathrm{Cl}$ & & $\mathrm{NO}_{3}$ & $\mathrm{SO}_{4}$ & \\
\hline 40 & 0 & $19.5 \pm 0.6$ & 40 & 20 & $20.5 \pm 0.4$ \\
\hline 30 & 10 & $20.3 \pm 0.1$ & 30 & 30 & $21.0 \pm 0.4$ \\
\hline 20 & 20 & $22.6 \pm 0.5$ & 20 & 40 & $23.2 \pm 0.2$ \\
\hline 10 & 30 & $23.0 \pm 0.1$ & 10 & 50 & $24.7 \pm 0.5$ \\
\hline 0 & 40 & - & 0 & 60 & - \\
\hline
\end{tabular}

tempting to interprete the improved growth with ammonium in terms of (C-A) higher of lower than the normal required for maximum growth.

To review this situation the data on dry matter yield and (C-A) of Table 2 are plotted for all series in Fig. 8. The yield was low when no potassium (a) or no nitrogen (b) was added with the nutrient salts, and both the yield and (C-A) were raised

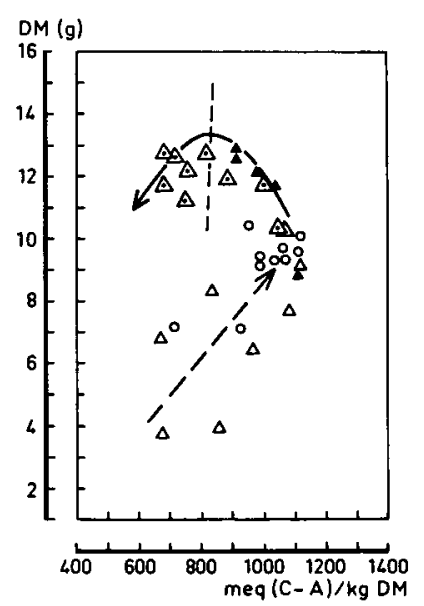

Fig. 8. Dry weight of tops and values for meq (C-A) per $\mathrm{kg}$ of dried tops. Open circles: Treatments a with increase in potassium. Open triangles: Treatments $\mathrm{b}$ with increase in $\mathrm{N}$ as nitrate. Filled triangles: Treatments $c_{3}$ with ammonium for nitrate in the presence of sulphate. Dotted triangles: Treatments $c_{1}$ and $c_{2}$, same in the presence of chlorides or phosphates. The broken line suggests effects of potassium and nitrate. The full-drawn curve is thought to reflect the effect of adding ammonium for nitrate: increase in yield and a shift of (C-A) to the lower normal level of 850 permitting maximum growth, not effected here because of some shortage of nitrogen. 
to a level of about $10 \mathrm{~g}$ with (C-A) at $1100 \mathrm{meq} / \mathrm{kg}$ if the supply of $\mathrm{K}$ and $\mathrm{N}$ was 40 meq per pot, with nitrate as the source of $\mathrm{N}$.

When, at the 40 meq per pot level of $N$, nitrate was replaced by ammonium (Treatments c), there was a further increase in yield and the concentration of (C-A) decreased. The points of Fig. 8 suggest that within the region of 1000 to $700 \mathrm{meq} / \mathrm{kg}$ DM there is no systematic change in yield with change in (C-A). Formally, this would mean that there is no discrete normal value for (C-A) permitting maximum growth. However it will be remembered that all treatments had shortage of $N$ at the time of harvest, so that there is every reason to assume that the plants were unable to perform maximum growth even at the most favourable ionic composition. If so, the highest yield level may comprise a certain range of values for $(\mathbf{C}-\mathrm{A})$ which includes the value at or near which maximum growth might have occurred if only there were sufficient $\mathrm{N}$ to support it.

A tentative way of arriving at a more precise value for the normal level of (C-A) is to assume that values below $700 \mathrm{meq} / \mathrm{kg}$ are certainly too low, and that all the recorded values were located within the region enclosed by the optimum curve drawn in Fig. 8. The value for the normal level of (C-A), indicating the most favourable ionic status of the plant for maximum growth would then appear to be about 850 $\mathrm{meq} / \mathrm{kg} \mathrm{DM}$. This value may serve as a guide in the planning of later experiments so as to obtain sufficient data for a diagnostic examination of the nutrient status. If this conclusion were valid, the preference for ammonium as the source of nitrogen would then be related to the fact that the rice plant accumulates carboxylates in excess of the normal level if nitrate is consumed, whereas substitution of ammonium for nitrate lowers the production of carboxylates to a sufficient extent to prevent excessive accumulation of carboxylates so that the normal level is maintained and better growth results.

This situation is known to occur in plants sensitive to lime-induced chlorosis, and in ericaceous species (Dijkshoorn, 1969). But for gramineous species it is unknown, and in this respect the nitrogen nutrition of rice plants in its relation to the ionic balance within the plant might seem to represent an interesting case of injury by nitrate, associated with excess of carboxylates in the tissues.

\section{References}

Dijkshoorn, W., D. J. Lathwell \& C. T. de Wit, 1968. Temporal changes in carboxylate content of ryegrass with stepwise change in nutrition. $\mathrm{Pl}$. Soil 29:369-390.

Dijkshoorn, W., 1969. The relation of growth to the chief ionic constituents of the plant. Proc. Symp. Brit. ecol. Soc. 9: 201-213.

Ehrler, W. \& L. Bernstein, 1958. Effect of root temperature, mineral nutrition and salinity on the growth and composition of rice. Bot. Gaz. 120:67-74.

Karim, A. Q. M. B. \& J. Vlamis, 1962. Comparative study on the effects of ammonium and nitrate nitrogen in the nutrition of rice. Pl. Soil 16: 32-41.

Kelly, W. P., 1911. The assimilation of nitrogen by rice. Bull. Hawai agric. Exp. St 24: 1-20.

Kirkby, E. A., 1969. Ion uptake and ionic balance in plants in relation to the form of nitrogen nutrition. Proc. Symp. Br. ecol. Soc. 9: 215-235.

Kostic, M., W. Dijkshoorn \& C. T. de Wit, 1967. Evaluation of the nutrient status of wheat plants. Neth. J. agric. Sci. 15: 267-280.

Malavolta, E., 1954. Studies on the nitrogenous nutrition of rice. Pl. Physiol. 29: 98-99.

Metzger, W. H. \& G. Janssen, 1928. The relation of sodium nitrate and certain other nitrogen carriers to the development of chlorosis in rice. J. agric. Res. 37: 589-602.

Tuil, H. D. W. van, J. E. M. Lampe \& W. Dijkshoorn, 1964. The possibility of relating the ashalkalinity to the organic salt content. Jaarb. Inst. biol. scheik. Onderz. LandbGew. 1964, 157-160. 
Tuil, H. D. W. van, 1965. Organic salts in plants in relation to nutrition and growth. Agric. Res. Rep. (Wageningen) 657 ; pp. 83 .

Wahhab, A. \& H. M. Bhatti, 1957. Effect of various sources of nitrogen on rice paddy yield. Agron. J. $49: 114-116$.

Willis, L. G. \& J. C. Carrers, 1923. Influence of some nitrogenous fertilizers on the development of chlorosis in rice. J. agric. Res. 24: 621-640.

Wit, C. T. de, W. Dijkshoorn \& J. C. Noggle, 1963. Ionic balance and growth of plants. Agric. Res. Rep. (Wageningen) 69.15 ; pp. 65. 